\title{
HUKUM QISHASH DIYAT: Sebuah Alternatif Hukuman Bagi Pelaku Kejahatan Pembunuhan Berencana di Indonesia
}

\author{
Sudarti \\ Universitas Islam Negeri (UIN) Sunan Kalijaga Yogyakarta \\ Email : sitisudarti29@gmail.com
}

\begin{abstract}
The research is purpose to know a provision of punishment qishash diyat which is in islamic law and to see what punishment of qishash diyat can be applyed as alternative for sanction of criminal act murder planned (deliberate) in Indonesia. In this case, it is consequence from deliberate murder plus persecution, theft, plunder and mutilation limbs of the victim. The research methodology that have been used is kualitative methodology. The result of research show that punishment of qishash on islamic law as alternative of sanction by them. Because of punishment it is be value more ensuring to justice, not only doer but also victim. Punishment of qishash diyat can make person where he will not do criminal acting. So, it used as instrument general prevention and special prevention also as learning to see that be importance to keep rights every human being and not violating.
\end{abstract}

Keywords: Qishash Diyat, Deliberate Murder, Punishment

\begin{abstract}
Abstrak
Penelitian ini bertujuan untuk mengetahui ketentuan hukuman qishash diyat yang ada dalam hukum Islam dan untuk melihat hukuman qishash diyat apa yang dapat diterapkan sebagai alternatif sanksi pidana pembunuhan berencana (sengaja) di Indonesia. Dalam hal ini merupakan akibat dari pembunuhan yang disengaja ditambah penganiayaan, pencurian, perampasan dan pemotongan anggota tubuh korban. Metodologi penelitian yang digunakan adalah metodologi kualitatif. Hasil penelitian menunjukkan bahwa hukuman qishash dalam hukum Islam sebagai alternatif sanksi oleh mereka. Karena hukuman itu menjadi nilai lebih menjamin keadilan, tidak hanya pelaku tetapi juga korban. Hukuman qishash diyat dapat membuat seseorang tidak melakukan tindak pidana. Jadi, digunakan sebagai instrumen pencegahan umum dan pencegahan khusus juga sebagai pembelajaran untuk melihat pentingnya menjaga hak setiap manusia dan tidak melanggar.
\end{abstract}

Kata Kunci: Qishash Diyat, Pembunuhan Sengaja, Hukuman

\section{PENDAHULUAN}

Persoalan yang tidak pernah luput dari sorotan berbagai kalangan masyarakat baik nasional maupun internasional adalah terkait dengan hukuman qishash atau hukuman mati. Hukuman qishash bahkan sering digunakan oleh beberapa kalangan untuk menjustifikasi ajaran Islam yang terkesan primitif, kejam, menakutkan dan tidak manusiawi (Arifin, 2016: 
172). Hal ini dikarenakan hukum pidana Islam hanya dipelajari secara parsial, belum dipahami secara menyeluruh sehingga menimbulkan persepsi bahwa qishash adalah hukum yang tidak berperikemanusiaan. Apabila qishash hanya dipahami secara tekstual maka yang terjadi akan demikian, namun apabila dikaji lebih mendalam akan ditemukan fakta bahwa hukum qishash justru memberikan keadilan tidak hanya bagi pelaku tetapi memberikan keadilan bagi korban dan keluarganya.

Kenyataannya tidak semua pelaku pembunuhan dijatuhi hukuman qishash. Hanya pembunuhan disengaja (berencana) dan tidak mendapatkan maaf dari korban dan keluarganya yang dapat dikenakan hukuman qishash. Dalam persoalan pembunuhan sengaja terdapat tiga bentuk hukuman yang dapat dikenakan pada pelaku, yakni hukuman asal, hukuman pengganti, dan hukuman tambahan.

Hukuman pokok pembunuhan sengaja adalah qishash. Hukuman ini diberlakukan apabila terdapat unsur rencana dan tipu daya serta tidak ada maaf dari pihak keluarga korban. Jika keluarga korban memaafkan maka hukuman penggantinya adalah diyat. Apabila sanksi qishash dan diyat dimaafkan maka hukuman penggantinya adalah $t a^{\prime} z i r$. Selanjutnya hukuman tambahan terhadap jarimah pembunuhan ini adalah terhalangnya hak atas waris dan wasiat.

Hukuman qishash dalam hukum pidana Islam sangat membantu pemantapan pola penegakan hukum (law enforcement) negara agar masyarakat memahami dan menaati kaidah hukum negara serta kaidah agama sekaligus. Hukum Islam ketika menerapkan hukuman qishash dan balas dendam bukanlah pertimbangan semata, melainkan menjustifikasi aturan konkrit tentang nilai-nilai keadilan artinya tidak boleh memberikan hukuman melebihi kesalahan seseorang. Spiritualitas hukum qishash diyat sangat memperhatikan aspek korban kejahatan dan yang terpenting adalah tidak memanjakan pelaku kejahatan tersebut.

Hukuman diyat (ganti rugi), ta'zir yang berupa penjara atau bahkan pembebasan (maaf) menjadi suatu hal yang mungkin untuk diterapkan dalam persoalan kejahatan pembunuhan. Sanksi diterapkan secara konsidional terkait dengan jenis pembunuhannya, siapa pelakunya, mengapa terjadi pembunuhan dapat menjadi pertimbangan hakim dalam memutuskan dan menjatuhkan suatu hukuman (Syahrur, 1990: 455). Anggapan masyarakat bahwa hukum qishash adalah hukuman yang primitif, kejam dan tidak berperikemanusiaan, ternyata suatu anggapan yang keliru. Hal ini dikarenakan tujuan dari pelaksanaan eksekusi qishash hanya bermaksud memberi peringatan keras bagi umat Islam agar tidak mudah menumpahkan darah pada sesamanya. Selain dalam rangka menjalankan syari'at agama, keistimewaan dari hukum qishash juga menonjolkan sifat pemaafan, sehingga seseorang bisa terbebas dari hukuman karena ahli waris memaafkan pelaku pembunuhan dan 
penganiayaan. Namun dalam hal ini, fikih jinayah juga telah menambah hak bagi Ulil Amri untuk menentukan hukuman sendiri meskipun ahli warisnya telah memaafkan. Dengan demikian sebenarnya hukuman qishash diyat lebih sederhana dan fleksibel.

Maraknya kasus pembunuhan sengaja di Indonesia, bahkan disertai dengan penganiayaan, pencurian, perampasan dan pemotongan (mutilasi) anggota tubuh menjadi sebuah keprihatinan tersendiri. Dalam rangka menjaga dan melindungi setiap orang dari kejahatan terhadap jiwa yakni pembunuhan disengaja atau pembunuhan berencana maka hukum Islam mengancam pelakunya dengan hukuman yang tegas berupa qishash diyat. Hukuman qishash disyariatkan untuk memelihara jiwa, karena seseorang yang hendak melakukan kejahatan ketika telah mengetahui akan dibalas dengan perbuatan yang serupa, niscaya dirinya tercegah melakukan tindakan jahatnya (Fannani, 2013: 1512).

Kajian penelitian tentang qishah pada dasarnya telah banyak dilakukan sebagaimana dalam penelitiannya Darussamin (2014) dengan judul "Qishah dalam Islam a dan Relevansinya dengan Masa Kini". Hasil kajian penelitian menunjukkan bahwa hukuman qishah dalam hukum Islam hakikatnya adalah hukuman mati yang penerapannya diberlakukan pada kasus pembunuhan dan kasus lainnya. Namun dalam praktiknya, jenis hukuman ini akan sulit diterapkan karena melibatkan negara, meskipun sebagian kalangan berpandangan bahwa hukuman qishah jika diterapkan akan memiliki implikasi luar biasa yaitu mampu mencegah kejahatan-kejahatan yang dapat dikualifikasikan kejahatan yang berat, kendati terjadi pro dan kontra dalam masalah tersebut.

C. Batubara (2010) dalam penelitiannya berjudul "Qishash Hukuman Mati dalam Perspektif al-Qur'an", mengatakan bahwa Islam sesungguhnya sangat berhati-hati dalam menjatuhkan hukuman, bahkan di dalam al-Qur'an dan Hadis memberi peluang yang cukup besar untuk menghindari jatuhnya sanksi apalagi yang berkaitan dengan nyawa atau badan. Meskipun secara eksplisit al-Qur'an menyebut kata qishah akan tetapi dalam hal ini Islam sangat menghargai kehidupan, oleh karenanya sebagai langkah terbaik yang dianjurkan adalah mendorong pihak keluarga untuk memafkan terpidana.

Hasil kajian sebelumnya tersebut setidaknya dapat dijadikan sebagai basis dalam penelitian yakni sama-sama mengkaji berkait dengan qishah, meskipun terdapat sisi perbedaan. Jika penelitian sebelumnya lebih mendiskripsikan qishah secara konseptual, namun penelitian ini lebih menfokuskan pada permasalahan tentang bagaimana ketentuan hukuman qishash diyat dalam hukum pidana Islam, apakah aspek keadilan dalam hukuman qishash diyat sehingga dapat dijadikan sebagai alternatif hukuman bagi pelaku pembunuhan berencana (sengaja) di Indonesia. Sehingga penelitian ini bertujuan untuk mendiskripsikan dan menjelaskan 
ketentuan hukuman qishash diyat dalam hukum pidana Islam sebagai sanksi bagi pelaku pembunuhan berencana (sengaja), dan menganalisisnya untuk melihat aspek keadilan dalam hukuman qishash diyat.

\section{METODE PENELITIAN}

Jenis penelitian yang digunakan dalam penelitian ini adalah penelitian kepustakaan (library research) dengan menelaah bahan-bahan dari buku utama yang berkaitan dengan masalah dan buku penunjang lainnya yang berkaitan dengan kajian penelitian yang bersifat kualitatif (Subagio, 1991: 109). Pendekatan penelitian yang digunakan adalah pendekatan yuridis-normatif. Pendekatan yuridis digunakan untuk menelaah aspek keadilan dalam hukum qishash diyat sebagai alternatif sanksi bagi pelaku pembunuhan berencana (sengaja) di Indonesia. Pendekatan normatif digunakan untuk menelaah ketentuan pemberlakuan sanksi tindak pidana pembunuhan berencana (sengaja) dalam hukum pidana Islam.

\section{PEMBAHASAN}

\section{Ketentuan Hukum Qishash Diyat dalam Hukum Pidana Islam}

Para ulama mendefinisikan pembunuhan sebagai perbuatan manusia yang menyebabkan hilangnya nyawa. Pembunuhan dapat diartikan pula sebagai suatu aktivitas yang dilakukan oleh seseorang dan atau beberapa orang yang mengakibatkan seorang dan atau beberapa orang meninggal dunia (Ali, 2012:24). Ulama Malikiyah membagi jenis pembunuhan menjadi dua, yaitu pembunuhan sengaja dan pembunuhan tidak sengaja. Sedangkan ulama Hanafiyah, Syafi'iyah, dan Hambali membagi pembunuhan menjadi tiga jenis, yaitu (1) pembunuhan sengaja (qatl al-amd) merupakan suatu perbuatan penganiayaan terhadap seseorang dengan maksud untuk menghilangkan nyawa oranglain, (2) pembunuhan semi sengaja (qatl syibh al-'amd) merupakan perbuatan penganiayaan terhadap seseorang tidak bermaksud untuk membunuhnya namun mengakibatkan kematian, (3) pembunuhan karena kesalahan (qatl al-khata') merupakan pembunuhan yang disebabkan salah dalam perbuatan, salah dalam maksud dan kelalaian (Munajat, 2010: 139).

Sanksi bagi pelaku pembunuhan sengaja adalah berupa hukuman pokok, hukuman pengganti, dan hukuman tambahan. Hukuman pokok untuk pembunuhan sengaja adalah qishash. Hukuman qishash diberlakukan apabila terdapat unsur rencana dan tipu daya, serta tidak mendapat maaf dari keluarga korban. Jika keluarga korban memaafkan maka hukuman pengganti yang dikenakan pada pelaku pembunuhan adalah diyat. Apabila hukuman qishash dan diyat dimaafkan oleh keluarga korban maka pelaku pembunuhan dikenakan hukuman pengganti berupa 
$t a^{\prime} z i r$, serta mendapatkan hukuman tambahan berupa terhalangnya hak atas warisan dan wasiat. Sanksi pokok bagi pelaku pembunuhan semi sengaja dan pembunuhan karena kesalahan adalah diyat dan kaffarat, sedangkan untuk hukuman penggantinya adalah puasa dan $t a^{\prime} z i$, serta mendapat hukuman tambahan berupa terhalangnya menerima warisan dan wasiat (Audah, 1963:286).

Dasar hukum dilarangannya melakukan pembunuhan terdapat dalam al-Quran surah Al-Isra' ayat 33:

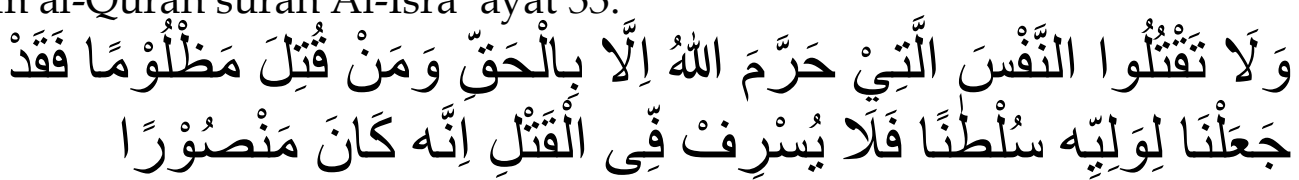

Artinya : "Dan janganlah kamu membunuh orang yang diharamkan Allah (membunuhnya), kecuali dengan suatu (alasan) yang benar. Dan barang siapa dibunuh secara zalim, maka sungguh, Kami telah memberi kekuasaan kepada walinya, tetapi janganlah walinya itu melampaui batas dalam pembunuhan. Sesungguhnya dia adalah orang yang mendapat pertolongan".

Tujuan dari adanya sanksi yaitu untuk memelihara dan menciptakan kemaslahatan, serta menjaga mereka dari hal-hal yang mafsadah. Islam sebagai agama yang rahmatan lil 'alamin bertujuan untuk memberi petunjuk dan pelajaran kepada manusia. Hukuman ditetapkan agar manusia dapat memperbaiki dirinya, memberikan perlindungan bagi masyarakat dan mewujudkan tertib sosial dalam hal ini menerapkan hukuman bagi pelaku pembunuhan.

Qishash dalam terminologi hukum Islam diartikan sebagai hukuman yang dijatuhkan sebagai pembalasan serupa dengan perbuatan pembunuhan, melukai atau merusak anggota badan berdasarkan ketentuan yang diatur oleh syara' (Mujib, 1994:278). Ada beberapa syarat yang harus dipenuhidalam melaksanakan hukuman qishashmenurut ulama fikih, yaitu (1) adanya kepastian pelaku kejahatan, (2) keterbatasan hukuman pada pelaku kejahatan,(3)pelaku pembunuhan sudah mukallaf,(4) pelaku pembunuhan bukan orang tua korban, (5) korban harus seorang yang maksum al-dam, (6) para penuntut qishash (mustahiq alqishash) harus sudah mukallaf, (7) semua penuntut qishash sepakat atas tuntutannya, (8) keputusan harus ditetapkan oleh pemerintah atau hakim, (9) pelaksanaan hukuman qishash harus dihadiri oleh pemerintah yang sah atau aparat penegak hukum yang berwenang, (10) pelaksanaan hukuman qishash harus disaksikan oleh ahli waris yang menuntut qishas (Burlian, 2015: 76-87).

Menurut pendapat mayoritas ulama Malikiyah, Syafi'iyah, dan salah satu riwayat Imam Ahmad, hukum asal pelaksanaan qishash yakni dengan cara yang sama dilakukan oleh pelaku kriminal tersebut atau disebut sebagai mutslah atau mumatsalah. Sehingga jika pelaku membunuh 
dengan pedang maka pelaku juga diqishash dengan pedang, jika pelaku membunuh dengan memukulkan batu sampai mati, maka pelaku diqishash dengan batu sampai mati, dan seterusnya. Namun hal ini tidak berlaku jika pelaku membunuh dengan sesuatu yang haram seperti sihir, khamar, liwath dan semisalnya. Apabila dengan cara yang sama dapat mengakibatkan pelaku terlalu lama tersiksa, maka qishasnya dengan pedang. Seandainya mustahiq al-qishash menggantinya dengan hukuman pancung menggunakan pedang, maka diperbolehkan dan itu lebih utama (Zuhaili, 2004 : 5685).

Menurut Abu Hanifah hukuman qishashharus dilakukan hanya dengan pedang, tidak dengan membalas seperti cara pelaku tersebut membunuh (Abidin, 1987 : 346). Ketentuan ini berlaku secara mutlak, baik pelaku pembunuhan tersebut membunuh dengan senjata ataupun tidak. Serta berlaku untuk pembunuhan yang dilakukan dengan pemenggalan leher, mencekik, melemaskan dalam air, membakar, atau yang lainnya.

Selanjutnya sanksi diyat. Secara terminologi syariat, diyat diartikan sebagai harta yang wajib dibayar dan diberikan oleh pelaku pembunuhan kepada korban atau walinya sebagai ganti rugi, disebabkan perbuatan pidana yang dilakukan oleh si pelaku kepada korban. Diyat dibagi menjadi dua, yaitu pertama, diyat kabir (denda besar) terdiri dari seratus ekor unta, dengan perincian 30 ekor unta betina umur 3 tahun masuk empat tahun, 30 ekor unta betina umur empat tahun masuk lima tahun, dan 40 ekor unta betina yang sudah hamil.

Diyat tersebut diwajibkan untuk mengganti hukuman qishash yang dimaafkan pada pembunuhan yang disengaja dan denda ini wajib dibayar tunai oleh pelaku pembunuhan sendiri. Selain itu bagi pelaku pembunuhan semi sengaja, denda ini wajib dibayar oleh keluarganya, diangsur dalam waktu selama tiga tahun, tiap-tiap akhir tahun wajib dibayar sepertiga. Kedua, diyat shaghir (denda ringan) berupa seratus ekor unta tetapi dibagi lima yakni 20 ekor unta betina berumur satu tahun masuk dua tahun, 20 ekor unta betina umur dua tahun masuk tiga, 20 ekor unta jantan umur dua tahun masuk tiga tahun, 20 ekor unta betina umur tiga tahun masuk empat, 20 ekor unta jantan umur empat tahun masuk lima. Denda tersebut wajib dibayar oleh keluarga pelaku pembunuhan dalam waktu tiga tahun, tiap akhir tahun dibayar sepertiganya. Jika denda tidak dapat dibayar dengan unta, maka wajib dibayar dengan uang sebanyak harga unta tersebut.

Selain qishash dan diyat, terdapat pula hukuman berupa kaffarat. Secara istilah, kaffarat diartikan sebagai denda yang wajib dibayarkan oleh seseorang yang telah melanggar larangan Allah. Kaffarat juga sebagai tanda taubat pada Allah dan penebus dosa. Terdapat beberapa macam kaffarat, yaitu (1) kaffarat pembunuhan diberlakukan pada pelaku pembunuhan karena selain dihadapkan pada dua pilihan antara diqishash 
atau membayar diyat, pelaku pembunuhan juga diwajibkan membayar kaffarat. (2) kaffarat dzihar, (3) kaffarat melakukan Jimak pada siang ramadhan, (4) kaffarat karena melanggar sumpah, (5) kaffarat ila', dan (6) kaffarat karena membunuh binatang buruan pada saat berihram.

Pemberian sanksi dalam hukum pidana Islam kepada pelaku pembunuhan mengandung nilai-nilai humanisme(Doi, 1992 : 24), yaitu pertama, hukum qishash diyat merupakan bentuk koreksi terhadap hukuman pada zaman jahiliyah yang sangat diskriminatif. Pada masa itu kabilah yang kuat berpeluang mendominasi keputusan hukum sehingga suku yang lemah akan selalu tertindas oleh suku yang kuat dan ketika diterapkan qishash tidak ada keadilan hukum antara kesalahan dengan hukuman yang harus diterima. Ketika terdapat keluarga yang terbunuh maka yang dibalas adalah pembunuh dan keluarganya yang tidak berdosa.

Islam datang melegitimasi hukum qishash dengan prinsip penegakan nilai-nilai keadilan dan persamaan di muka hukum tanpa memandang kabilah maupun kehormatan. Kedua, menegakkan nilai-nilai keadilan demi tegaknya supremasi hukum, baik pada saat merevisi hukum jahiliyah maupun kebutuhan hukum untuk sepanjang zaman. Ketiga, perlindungan bagi korban atau walinya secara langsung.

Islam mengajarkan adanya persamaan (equality), kemurahan hati (mercy) dengan menetapkan bahwa pembunuhan dibalas dengan pembunuhan (qishash), serta penganiayaan dibalas dengan penganiayaan. Namun jika pelaku pembunuhan dimaafkan, maka diganti dengan membayar diyat yang reasonable. Sebagaimana dijelaskan oleh Al-Jurjawi bahwa hikmah dari adanya hukuman qishash diyat adalah keberlangsungan hidup manusia di dunia karena Islam menghukum orang yang membunuh orang lain sebagai langkah preventif agar manusia tidak mudah saling membunuh. Adanya hukuman qishash dapat menghindari kemarahan dan dendam dari keluarga korban yang terbunuh supaya dendam tersebut tidak berkelanjutan yang dapat menyebabkan saling bunuh antar keluarga.

Selain itu, hikmah dari adanya hukuman diyat adalah untuk kepentingan dua belah pihak. Dengan membayar denda secara damai kepada keluarga terbunuh, maka pembunuh akan merasakan kehidupan baru yang aman dan bertaubat ke jalan yang benar, serta dapat menyadari betapa berharganya kehidupan. Bagi keluarga korban pembunuhan yang menerima denda dengan damai dapat memanfaatkan harta tersebut untuk keberlangsungan hidupnya dan meringankan sedikit beban kesedihannya.

Wahbah Az-Zuhaili menjelaskan bahwa alat-alat bukti dalam menetapkan sebuah kejahatan yang mengakibatkan qishash atau diyat meliputi: pertama, pengakuan. Syarat pengakuan dalam tindak pidana 
yang berakibat qishash atau diyat adalah harus jelas dan terperinci. Pengakuan yang umum dan masih terdapat syubhat akan mengakibatkan tidak sah. Kedua, persaksian. Syarat minimal adalah 2 orang saksi lelaki yang adil. Apabila terdakwa mengingkari kesaksian dua saksi tersebut, maka terdakwa harus bersumpah atas pengingkarannya tersebut, dan dilakukan pembuktian terbalik. Ketiga, menarik diri dari bersumpah yakni ketika terdakwa menarik diri (mengelak) dari bersumpah yang diajukan kepada terdakwa melalui hakim.Keempat,al-qasamah yakni sebuah sumpah yang diulang-ulang pada kasus pidana pembunuhan. Sumpah dilakukan sebanyak 50 kali sumpah dari 50 laki-laki.

\section{Analisis Aspek Keadilan dalam Hukuman Qishash Diyat}

Qishash diyat merupakan suatu hukuman bagi kejahatan terhadap jiwa (menghilangkan nyawa) dan anggota badan (pelukaan) yang diancam dengan hukuman qishash (serupa atau semisal) atau hukum diyat (ganti rugi dari pelaku atau ahlinya kepada korban atau walinya. Dalam hukum pidana Islam yang termasuk dalam jarimah qishash diyatini meliputi: (1) pembunuhan dengan sengaja, (2) pembunuhan semi sengaja, (3) menyebabkan matinya orang karena kealpaan atau kesalahan, (4) penganiayaan dengan sengaja, dan (5) menyebabkan orang luka karena kealpaan atau kesalahan (Munajat, 2010: 135).

Sabiq (1987) berpendapat bahwa keadilan merupakan salah satu dari nilai-nilai Islam yang tinggi. Keadilan dapat diwujudkan dengan menyampaikan setiap hak kepada yang berhak dan dengan melaksanakan hukum-hukum yang telah disyariatkan Allah serta dengan menjauhkan hawa nafsu melalui pembagian yang adil di antara sesama manusia.

Keadilan dalam Islam sama dengan suatu kewajiban yang dibebankan kepada manusia untuk dilaksanakan dengan sungguhsungguh dan jujur, tidak boleh ada unsur subjektif dalam defenisi keadilan, apa yang dianjurkan oleh Islam adalah sikap berpikir yang reflektif dan pendekatan yang objektif terhadap masalah yang dihadapi. Dengan demikian keadilan merupakan kualitas berlaku adil secara moral dan rahmat dalam memberikan kepada setiap manusia akan haknya (Minhajuddin, 1996: 171).

Secara etimologis al-adl diartikan sebagai tidak berat sebelah, tidak memihak, atau menyamakan yang satu dengan yang lain. Istilah lain dari al-adl adalah al-qist al-misl (sama bagian atau semisal). Adil adalah mempersamakan sesuatu dengan yang lain, baik dari segi nilai maupun dari segi ukuran, sehingga sesuatu itu menjadi tidak berat sebelah dan tidak berbeda satu sama lain. Adil juga berarti berpihak atau berpegang kepada kebenaran (Dahlan, 1997: 25).

Ali (2007) menjelaskan bahwa hukum qishash sebagai bagian dari hukum pidana Islam secara menyeluruh berpegang pada asas keadilan 
yang mendasari proses pemeriksaan serta sasaran yang akan dicapai dari proses peradilan yang adil. Pelaksanaan hukuman qishashyang bertujuan untuk menghormati hak setiap individu. Dalam hukum qishash tersebut, terdapat hak Allah yang wajib dilaksanakan (tidak dapat diganggu gugat oleh manusia) apabila telah memenuhi semua syarat-syarat penghukuman, yaitu apabila dalam tindakan tersebut terbukti secara meyakinkan melakukan pembunuhan (menghilangkan nyawa) atau penganiayaan orang lain secara sengaja.

Burlian (2015) berpendapat bahwa hukuman qishash sebagai hukuman yang paling adil. Hal ini dapat dilihat bahwa secara fitrah keluarga korban pembunuhan tentu menginginkan agar pelaku pembunuhan dihukum seberat-beratnya atau hukuman yang setimpal. Pada hakikatnya hukuman penjara tidak menimbulkan kepuasan hati keluarga korban.

Hukum qishash diyat sesuai dengan tujuan pemidanaan dalam Islam yaitu retribution (pembalasan), deterence (pencegahan), dan reformation (perbaikan). Sebagai retribution (pembalasan yang setimpal) karena hukum qishashhanya diberlakukan pada orang-orang yang telah melakukan perbuatan tindak pidana pembunuhan dengan sengaja. Sebagai deterence (pencegahan yang kuat) karena dengan menghukum qishash orang yang telah membunuh orang lain dengan sewenang-wenang akan memutuskan perbuatan kriminal tersebut, serta bertujuan agar perbuatan kriminal tersebut tidak berulang terus menerus, sekaligus menjadi contoh yang sangat berharga bagi setiap orang untuk tidak mudah melakukan pembunuhan.Sebagai reformation (perbaikan) dapat dipahami bahwa dalam hukum qishashterdapat kemungkinan pemaafan dari pihak keluarga. Reformation juga dimaksudkan untuk memperbaiki legalitas hukum yang harus ditaati oleh setiap orang supaya tidak membunuh dan menganiaya orang lain, sehingga tercipta masyarakat yang semakin baik dan tentram (Santoso, 2000: 140).

Berdasarkan laporan Statistik Kriminal 2020 dari Badan Pusat Statistik menyatakan bahwa selama periode lima tahun terakhir, jumlah kejahatan terhadap nyawa (pembunuhan) di Indonesia masih tinggi meskipun cenderung menurun. Pada tahun 2015 tercatat ada 1.491 kejadian (tertinggi pada kurun waktu lima tahun terakhir). Angka ini menurun pada tahun 2016 menjadi 1.292 kejadian, tahun 2018 menjadi 1.024 kejadian, dan turun kembali menjadi 964 kejadian pada tahun 2019. Namun penurunan kasus pembunuhan pada kurun waktu lima tahun terakhir tersebut justru dibarengi pula dengan beberapa kasus pembunuhan yang semakin sadis dilakukan oleh pelaku, seperti pembunuhan yang disertai dengan pemotongan anggota tubuh korbannya (mutilasi). Sepanjang tahun 2020 sejumlah kasus pembunuhan 
disertai mutilasidilakukan para pelakunya dengan berbagai motif, mulai dari dendam, asmara, hingga perampokan.

Tercatat pada tahun 2020 terdapat beberapa kasus pembunuhan disertai mutilasi yang menjadi sorotan publik tanah air. Seperti kasus suami yang melakukan mutilasi terhadap istrinya di Sumbawa karena motif cemburu pada korban; pembunuhan disertai mutilasi tubuh korban wanita muda oleh mantan narapidana asusila di Deli Serdangkarena korban menolak ajakan pelaku untuk melakukan perbuatan asusila; kasus pembunuhan disertai mutilasi yang dilakukan oleh oknum TNI terhadap istrinya dilatarbelakangi wanita selingkuhan di Tapanuli Tengah; pembunuhan disertai mutilasi yang dilakukan oleh sejoli dengan motif ekonomi karena ingin menguasai harta korban di Apartemen Pasar Baru Mansion, Jakarta Pusat; dan masih banyak lagi kasus-kasus pembunuhan yang disertai dengan mutilasi tubuh korbannya.

Ancaman hukuman terhadap pelaku pembunuhanpun bervariasi, mulai dari hukuman penjara dalam kurun waktu tertentu hingga seumur hidup dan hukuman mati tergantung dari motif para pelakunya. Ketentuan Kitab Undang-Undang Hukum Pidana (KUHP) mengancam dengan pidana penjara paling lama lima belas tahun bagi pelaku pembunuhan yang dikategorikan biasa (Pasal 338 KUHP), pembunuhan dengan pemberatan diancam dengan hukuman penjara seumur hidup atau penjara sementara selama-lamanya dua puluh tahun (Pasal 339 KUHP), dan mengancam dengan pidana mati atau pidana penjara seumur hidup atau selama waktu tertentu, paling lama dua puluh tahun bagi pelaku pembunuhan berencana (Pasal 340 KUHP).

Ketentuan sanksi yang tertuang dalam KUHP tersebut terlihat hanya memberikan keadilan bagi pelaku dan belum mengakomodir hak korban atau anggota keluarga korban yang ditinggalkan. Bagaimana jika yang dibunuh merupakan kepala keluarga atau tulang punggung keluarga sebagai pencari nafkah bagi keluarganya? Bagaimana nasib anggota keluarga yang ditinggalkan? Jika mengacu pada ketentuan dalam KUHP maka anggota keluarga yang ditinggalkan tidak akan mendapatkan hak apapun. Apabila putusan hakim menjatuhkan hukuman mati pada pelaku, barangkali bagi keluarga korban hal ini sudah setara dengan perbuatannya namun apabila hakim hanya menjatuhkan hukuman penjara dalam waktu tertentu saja maka keluarga korban tetap tidak akan mendapatkan haknya dan nasib mereka akan semakin sulit lantaran kehilangan tulang punggung keluarganya. Belum lagi jika keluarga korban tidak terima maka akan sangat rawan terjadi dendam antara dua keluarga.

Persoalan tersebut sudah selayaknya mendapat perhatian khusus dari pemerintah. Hukum sebagai prinsip dalam mewujudkan keadilan harus mampu memberikan rasa adil bagi pelaku dan korban. Penulis 
berpendapat bahwa sanksi bagi pelaku pembunuhan berencana (sengaja) dalam KUHP dapat dikatakan belum sepenuhnya memberikan rasa keadilan khususnya bagi korban dan keluarga atau ahli warisnya. Hal ini dikarenakan KUHP belum mengakomodir hak korban atau anggota keluarga korban yang seharusnya juga perlu mendapat perhatian. Berbeda dengan ketentuan dalam hukum pidana Islam yang mengakomodir hak korban atau keluarganya. Ketika terjadi tindak pidana pembunuhan maka pihak keluarga atau ahli waris dari korban berhak ikut menentukan sanksi pidananya adalah, apakah pelaku akan dijatuhi hukuman, atau dimaafkan dengan membayar diyat atau dimaafkan secara cuma-cuma.

Hal ini menunjukkan bahwa tindak pidana pembunuhan dalam hukum pidana Islam tidak hanya berfokus pada hukuman bagi pelaku, akan tetapi juga melibatkan keluarga korban yang artinya hukum pidana Islam juga memperhatikan keluarga yang ditinggalkan. Misalnya dalam penentuan diyat, keluarga korban diberikan kesempatan untuk ikut bermusyawarah dalam penentuan jumlah diyat yang harus dibayarkan oleh pelaku akibat perbuatannya. Senada dengan hikmah diyat dalam pembunuhan sengaja menurut Al-Jurjawi, yakni ketika pelaku membayar uang ganti rugi kepada keluarga korban dengan cara damai yang dikehendaki dari pihak keluarga korban, maka pelaku telah menghidupkan kehidupan baru, keluarga korban merupakan penyebab satu-satunya bagi hidupnya pelaku. Hal ini menunjukkan kemuliaan hati para keluarga korban atau ahli warisnya (Salim, 2020 : 431).

Pada kenyataannya sanksi tindak pidana pembunuhan dalam hukum pidana Islam yang terkesan kejam dan tidak manusiawi tidaklah sepenuhnya benar, karena hukuman qishash bukanlah satu-satunya sanksi yang diberlakukan bagi pelaku pembunuhan. Qishash merupakan hukuman terakhir ketika pelaku tidak memperoleh pemafaan dari keluarga atau ahli waris korban. Jika pelaku tersebut mendapat pemaafan dari keluarga atau ahli waris korban maka pelaku tidak dijatuhi hukuman qishash, melainkan hukuman lain seperti hukuman diyat, kifarat, dan hukuman $t a^{\prime} z i r$.

Begitu pula ketika keluarga atau ahli waris korban memaafkan pelaku secara cuma-cuma akan memungkinkan pelaku pembunuhan tidak mendapatkan sanksi pidana apapun. Dalam hal ini hakim tidak bertindak sendirian dalam memutuskan hukuman bagi pelaku, melainkan melibatkan anggota keluarga atau ahli waris korban dalam penentuan sanksi pidana bagi pelaku. Hal ini pula yang membedakan antara sanksi pidana dalam hukum pidana Islam dan hukum positif sebagaimana yang terdapat dalam KUHP. Dalam KUHP, penjatuhan sanksi pidana sepenuhnya menjadi wewenang hakim dan tidak melibatkan keluarga atau ahli waris dalam penentuan sanksi bagi pelaku. 
Hak korban dalam tindak pidana qishash-diyat sangat jelas menggambarkan penghargaan yang tinggi terhadap prinsip keadilan. Pada kasus pembunuhan, hakuntuk mewujudkan sanksi sepenuhnya ada pada keluarga atau ahli waris korban, setelah melalui persidangan di pengadilan dan mendapatkan putusan tetap. Ketika pihak keluarga atau ahli waris korban memilih untuk memaafkan pelaku maka akan ada dua pilihan yakni, apakah pihak korban akan menuntut ganti rugi berupa diyat dengan sejumlah uang ataukah akan memaafkan sepenuhnya tanpa menuntut diyat. Inilah prinsip keadilan yang ditawarkan hukum pidana Islam melalui pengakuan terhadap hak-hak korban.

Terkadang hukuman penjara bukanlah solusi terbaik bagi pelaku maupun keluarga atau ahli waris korban, karena belum tentu pelaku menjadi jera dan takut untuk melakukan tindak pidana kembali setelah bebas dari penjara mengingat tidak sedikit pelaku yang justru kembali mengulangi kejahatan yang sama. Selain itu pelaku akan menjadi tidak produktif atau mengurangi produktivitas pelaku ketika berada dijeruji besi. Bagi keluarga atau ahli waris korban tidak jarang merasa dirugikan lantaran putusan hakim yang terkesan subjektif, sedangkan hak keluarga atau ahli waris cenderung luput dari perhatian. Begitu pula hukuman penjara dalam kurun waktu tertentu membutuhkan anggaran dana yang tidak sedikit dari negara dan tentu ini akan menambah beban negara. Dengan demikian, hukuman qishash diyat dipandang lebih memberikan ruang bagi keluarga atau ahli waris korban untuk mendapatkan rasa keadilan yang sesungguhnya.

Kejahatan terhadap nyawa (Pembunuhan) merupakan salah satu kejahatan yang paling tinggi hierarkinya dalam klasifikasi kejahatan internasional. Jumlah kejadian tidak mencerminkan jumlah korban karena pada satu kejadian bisa jadi lebih dari satu orang. Tingginya angka kasus pembunuhan di Indonesia, baik itu pembunuhan berencana (disengaja) maupun pembunuhan tidak sengaja dengan berbagai motifnya menjadi masalah yang krusial dan membutuhkan penanganan yang serius dari pemerintah maupun aparat penegak hukum. Tindakan preventif (pencegahan) terhadap tindak pidana pembunuhan harus dilakukan guna menekan laju peningkatan angka kasus pembunuhan yang terjadi, memberikan efek jera dan untuk memberikan kesadaran pada masyarakat supaya tidak mudah saling membunuh.

Hukuman qishash diyat dalam hukum pidana Islam dapat menjadi sebuah alternatif sanksi pidana bagi pelaku pembunuhan di Indonesia. Hukuman qishash diyat dinilai lebih menjamin rasa keadilan, tidak hanya bagi pelaku pembunuhan namun juga keadilan bagi keluarga korban pembunuhan yang kehilangan anggota keluarganya (Madjrie, 2003:21). Hukuman qishash diyat bisa membuat orang mengurungkan niatnya untuk melakukan tindak pidana, sehingga bisa dijadikan sebagai alat yang baik 
untuk prevensi umum maupun prevensi khusus sekaligus pembelajaran bagi khalayak akan arti pentingnya menjaga hak-hak setiap manusia dan tidak melanggarnya.

Jazairi (1964) berpendapat bahwa qishash merupakan hukum berkemanusiaan yang adil dan beradab. Dikatakan berkemanusiaan karena qishash sangat menghargai nyawa manusia dengan cara tidak boleh saling melukai dan membunuh kecuali dengan al-haq (adanya alasan hukum atau perintah agama). Hukum qishash sesuai dengan prinsip keadilan karena qishash menghendaki kejahatan dibalas dengan kejahatan yang serupa (hukuman setimpal). Dengan hukuman tersebut diharapkan manusia tidak saling bermusuhan, saling menjaga keamanan, memupuk persaudaraan, sehingga tercipta masyarakat yang beradab yang terjauh dari kekacauan. Dalam konteks Indonesia dimana saat ini tingkat perkembangan kasus-kasus pembunuhan masih tinggi dan memprihatinkan, karena bentuk pembunuhan yang begitu sadis dan kejam hingga pemotongan (mutilasi) anggota tubuh maka hukuman qishash diyat ini layak untuk dipertimbangkan. Dengan penolakan pemberian maaf dan diyat sebagai ganti qishash mungkin dapat menimbulkan rasa takut dan efek jera individu untuk melakukan kejahatan pembunuhan sengaja yang kejam.

\section{SIMPULAN}

Hukuman bagi pelaku pembunuhan sengaja dalam Islam berupa hukuman pokok yakni qishash. Qishash diberlakukan apabila terdapat unsur rencana dan tipu daya, serta tidak mendapat maaf dari keluarga korban. Jika keluarga korban memaafkan maka hukuman penggantinya adalah diyat. Apabila hukuman qishash dan diyat dimaafkan oleh keluarga korban maka dikenakan hukuman pengganti berupa $t a^{\prime} z i r$, serta mendapatkan hukuman tambahan berupa terhalangnya hak atas warisam dan wasiat. Sanksi pokok bagi pelaku pembunuhan semi sengaja dan pembunuhan karena kesalahan adalah diyat dan kaffarat, sedangkan untuk hukuman penggantinya adalah puasa dan $t a^{\prime} z i r$, serta mendapat hukuman tambahan berupa terhalangnya menerima warisan dan wasiat.

Hikmah dari hukuman qishash diyat adalah keberlangsungan hidup manusia di dunia karena Islam menghukum orang yang membunuh orang lain sebagai langkah preventif agar manusia tidak mudah saling membunuh. Hukuman qishash diyat dalam hukum pidana Islam dapat menjadi sebuah alternatif sanksi pidana bagi pelaku pembunuhan di Indonesia karena dapat menjamin rasa keadilan, tidak hanya bagi pelaku pembunuhan namun juga keadilan bagi keluarga korban pembunuhan yang kehilangan anggota keluarganya.

\section{DAFTAR PUSTAKA}

\section{Buku-buku}


Al-Fannani, Zainuddin bin Abdul Aziz Al-Malibari. (2013). Fathul Mu'in Jilid 2. Penerjemah Moch Anwar, dkk. Bandung. Sinar Baru Algensindo.

Ali, Muhammad Daud. (2005). Hukum Islam: Pengantar Ilmu Hukum dan Tata Hukum Islam di Indonesia. Jakarta. Raja Grafindo Persada.

Ali, Zainuddin. (2012). Hukum Pidana Islam. Jakarta. Sinar Grafika.

Al-Jurjawi. (t.t.). Hikmah at-Tasyri' wa Falsafatuhu. Beirut. Dar al-Fikr.

Burlian, Paisol. (2015). Implementasi Konsep Hukuman Qishash di Indonesia. Jakarta. Sinar Grafika.

Chazawi, Adami. (2002). Kejahatan Terhadap Tubuh dan Nyawa. Jakarta. Raja Grafindo Persada.

Djazuli, A. Figh Jinayah Upaya Menanggulangi Kejahatan dalam Islam. Jakarta. Raja Grafindo Persada.

Hakim, Rahman. (2011). Hukum Pidana Islam. Jakarta. Sinar Grafika.

Hanafi, A. (2002). Azas-azas Hukum Pidana Islam. Jakarta. Bulan Bintang.

Hasan, Musthofa dan Beni Ahmad Saebani. (2013). Hukum Pidana Islam Fiqh Jinayah. Bandung. Pustaka Setia.

Irfan, M. Nurul dan Masyrofah. (2013). Figh Jinayah. Jakarta. Amzah.

Madjrie, Abdurrahman dan Fauzan al-Anshari. (2003). Qisas; Pembalasan Yang Hak. Jakarta. Khairul Bayan.

Maulana, Sofyan. (2004). Hukum Pidana Islam dan Pelaksanaan. Jakarta. Rineka Cipta.

Munajat, Makhrus. (2010). Fikih Jinayah (Hukum Pidana Islam). Yogyakarta. Pesantren Nawesea Press.

Muslich, Ahmad Wardi. (2005). Hukum Pidana Islam. Jakarta. Sinar Grafika.

\section{Jurnal-Jurnal}

Arfa, Faisar Ananda. (2014). Denda Sebagai Alternatif Hukuman (Kajian Hukum Islam kontemporer). Jurnal Analytica Islamica, Volume 3 Nomor 1 Tahun 2014.

Arifin, M. Amin. (2016). Pidana Mati Menurut Hukum Nasional Dalam Hubungannya Dengan Hukum Islam. Jurnal Al-Ahkam, Volume 4 Nomor 3 Tahun 2016.

Baidlowi, Azalea Zahra. (2017). Kajian Yuridis Tentang Perbarengan Melakukan Tindak Pidana Pembunuhan Berencana Berdasarkan Pasal 340 KUHP. Jurnal Lex Et Societatis, Volume 5 Nomor 9 November 2017. 
Hadana, Erha Saufan, Beri Rizqi. (2020). Konsep Keadilan Terhadap Delik Pembunuhan (Analisis Komparatif Hukum Islam dan KUHP). Jurnal Legitimasi, Volume 9 Nomor 2 Juli-Desember 2020.

Khasan, Moh. (2017). Prinsip-Prinsip Keadilan Hukum dalam Asas Legalitas Hukum Pidana Islam. Jurnal Rechtsvinding, Volume 6 Nomor 1 April 2017.

Mentari, Besse Muqita Rijal. (2020). Saksi Pidana Pembunuhan Dalam Kitab Undang-Undang Hukum Pidana Dengan Hukum Islam. Jurnal Al-Ishlah, Volume 22 Nomor 1 Mei 2020.

Pratama, Widhy Andrian. (2019). Penegakan Hukuman Mati Terhadap Pembunuhan Berencana. SIGn Jurnal Hukum, Volume 1 Nomor 1 September 2019.

Pusposari, Asih. (2020). Pemberian Grasi dan Maaf dalam Bingkai Kajian Teoritik Tindak Pidana Pembunuhan (Studi Komparatif Hukum Positif dan Hukum Islam. Jurnal Al-Ahkam, Volume 5 Nomor 1 Tahun 2020.

Rafid, Noercholis. (2019). Asas Manfaat Sanksi Pidana Pembunuhan Dalam Hukum Pidana Nasional. Jurnal Al-Syakhshiyyah, Volume 1 Nomor 2 Desember 2019.

Rajafi, Ahmad. (2010). Qishash dan Maqashid Al-Syariah (Analisis Pemikiran asy-Syathibi dalam Kitab Al-Muwafaqat). Jurnal AlSyir'ah, Volume 8 Nomor 2 Desember 2010.

Romadhan, Dedi, dkk. (2021). Analisis Putusan Hakim dalam Tindak Pidana Pembunuhan Berencana (Putusan Nomor 74/pid.b/2019/pn.dps). Jurnal Interpretasi Hukum, Volume 2 Nomor 1 April 2021.

Salim, Pebri. (2020). Diyat Berdasarkan Gender Sebagai Pengganti Qishas Dalam Tindak Pidana Pembunuhan (Studi Analisis Hukum Pidana Islam). Jurnal Al-Qanun, Volume 1 Nomor 4 Desember 2020.

Sari, Devi Nilam. (2020). Implementasi Hukuman Qisas Sebagai Tujuan Hukum Dalam Al-Qur'an. Jurnal Muslim Heritage, Volume 5 Nomor 2 Tahun 2020.

Sinulingga, Rafida. (2020). Studi Komparasi Sanksi Pidana Pembunuhan dalam Kitab Undang-Undang Hukum Pidana (KUHP) dengan Hukum Islam dalam Rangka Pembaharuan Hukum Pidana. Sultan Agung Fundamental Research Journal, Volume 1 Nomor 1 Januari 2020.

Wulandari, Anita. (2020). Tinjauan Hukum Pidana Islam Terhadap Tindak Pidana Pembunuhan Berencana Dalam Kitab Undang-Undang 
Hukum Pidana. Jurnal Al-Hakim, Volume 2 Nomor 1 Mei 2020.

Yanri, Fuad Brylian. (2017). Pembunuhan Berencana. Jurnal Hukum dan Keadilan, Volume 4 Nomor 1 Maret 2017.

Yeni, Fitri, dkk. (2017). Pemrofilan Kriminal Pelaku Pembunuhan Berencana. Jurnal Psychopolytan, Volume 1 Nomor 1 Agustus 2017. 